\title{
Comparative Study of Proline Accumulation of some Varieties of Durum Wheat (Triticum durum Desf.) under Water Stress Conditions
}

\author{
Yasmina SEMIANI ${ }^{1 *}$, Marie Stella. BRADEA ${ }^{1}$, Abdelkader BENBELKACEM ${ }^{2}$, Mohammed SEMIANI ${ }^{3}$ \\ ${ }^{1}$ Blida 1 University, \\ ${ }^{2}$ Research Division in Biotechnology and Plant Breeding Division (INRAA), \\ ${ }^{3}$ Research Division in Bioclimatology and Agricultural Hydraulic (INRAA). \\ * corresponding author: semiani_y@yahoo.fr \\ Bulletin UASVM series Agriculture 73(2)/2016 \\ Print ISSN 1843-5246; Electronic ISSN 1843-5386 \\ DOI 10.15835/buasvmcn-agr: 12425
}

\begin{abstract}
Proline accumulation, as a marker of resistance to the abiotic constraints, was evaluated on seventeen genotypes of Durum wheat (Triticum Durum Desf) under water stress conditions. An experiment was implemented at INRAA research station located at Baraki, Algiers. The experimental design adopted is that of split plot design with water regime (irrigated and non irrigated treatments) as main plots and varieties as sub plots and three repetitions. Proline accumulation was significantly increased under water stress $(\mathrm{p}<0.01)$. There was differences between varieties and their interaction with water regimes $(\mathrm{p}<0.001)$ and 04 groups were identified. When plants are subjected to water stress they increase their rate of proline, this enables to improve the capacity of the cell to maintain it turgor pressure at low water potential.
\end{abstract}

Keywords: durum wheat (Triticum durum Desf.), proline accumulation, resistance, water stress.

\section{INTRODUCTION}

Environmental stresses, including drought stress are one of the first factors in limiting plant growth and crop productivity (Wang et al., 2003). It affects strongly the arid and semi arid zones, characterized by low and irregular rainfall and high temperatures.

In Mediterranean areas, especially in Algeria, durum wheat (Triticum durum Desf.) is an important crop. Wheat production is not sufficient to meet the demand of a growing population. The average consummation is estimated at more than $190 \mathrm{Kg} /$ years per person, where a total requirement is around 7.3 million tons for a population more than 38.7 million. The average production is estimated at 21 million quintals, resulting in coverage of imports of around 69\%. The cost of these imports amounted to more than 1.5 billion dollars. This situation affects the economical situation of the country. The primary constraint affecting this crop production is water scarcity.

Several studies showed that under water stress, plants adopt many strategies for adaptation which differ from one species to another and that involve a large combination of morphological, physiological and biochemical factors (Monneveux \& Belhassen, 1997).

To maintain a high osmotic pressure in the cell after the fall of the water potential caused by water stress (El Mourid, 1988 ; Casals, 1996), plants accumulate some osmoticums such as proline, which seems played a major role. Its accumulation in many plants under water stress was highlighted, in particular in barley by Savitskaya (1967) and in durum wheat by Tyankova (1967) and by Vlasyuk et al. (1968).

Proline accumulation is a common physiological response in many plants in response to a wide range to biotic and abiotic stresses. 
Proline accumulation has been reported to occur after salt, drought, hight temperature, low temperature, heavy metal, pathogen infection, anaerobiosis, nutrient deficiency, atmospheric pollution and UV irradiation (Hare and Cress 1997; Saradhi et al. 1995; Siripornadulsil et al. 2002.). SINGH et al. (1973) noted that in cereals, eventually in durum wheat under water stress conditions, proline accumulation even more important than genotypes are more resistant.

The present study aims to evaluate the affect of water stress on proline accumulation in some cultivars of Durum Wheat (Triticum durum Desf.).

Tab. 1. List of the genotypes studied

\begin{tabular}{|c|c|c|c|}
\hline $\mathrm{N}^{\circ}$ & Varieties or lines & Pedigree & Origin \\
\hline 1 & LD357E/2*TC60//J069/3/FG0/4/GTA/5/SRN_1/6/... & $\begin{array}{c}\text { CDSS04Y00755T- } \\
\text { 0T0PB-12Y-0M- } \\
\text { 06Y-1M-1Y-0B }\end{array}$ & Rép1-11 \\
\hline 2 & SORA/2*PLATA_12/3/SORA/2*PLATA_12//SOMAT_3/4/AJAIA_13/... & $\begin{array}{c}\text { CDSS02B00849T- } \\
\text { 0T0PB-0Y-0M-7Y- } \\
\text { 2M-04Y-0B }\end{array}$ & Rép1-15 \\
\hline 3 & CND/VEE//CELTA/3/PATA_2/6/ARAM_7//CREX/ALLA/5/ENTE/... & $\begin{array}{c}\text { CDSS02B00429S- } \\
\text { 0M-9Y-06Y-1M- } \\
\text { 1Y-0B }\end{array}$ & Rép1-21 \\
\hline 4 & MINIMUS/COMB DUCK_2//CHAM_3/3/RCOL*2/4/... & $\begin{array}{c}\text { CDSS02B01108T- } \\
\text { 0T0PB-0Y-0M-5Y- } \\
\text { 4M-04Y-0B }\end{array}$ & Rép1-09 \\
\hline 5 & Beni Mestina & Témoin & Témoin \\
\hline 6 & MINIMUS_6/PLATA_16//IMMER/3/SOOTY_9/... & $\begin{array}{c}\text { CDSS02B00396S- } \\
\text { 0M-4Y-06Y-4M- } \\
\text { 1Y-0B }\end{array}$ & Rép1-03 \\
\hline 7 & PLATA_7/ILBOR_1//SOMAT_3/3/CABECA_2/PATKA_4//ZHONG ZUO/. & $\begin{array}{c}\text { CDSS04Y00053S- } \\
\text { 13Y-0M-06Y-4M- } \\
\text { 1Y-0B }\end{array}$ & Rép1-16 \\
\hline 8 & MINIMUS/COMB DUCK_2//CHAM_3/3/RCOL*2/4/SOMAT_4/INTER_8 & $\begin{array}{c}\text { CDSS02B01108T- } \\
\text { 0T0PB-0Y-0M-5Y- } \\
\text { 4M-04Y-0B }\end{array}$ & Rép1-19 \\
\hline 9 & BCRIS/BICUM//LLARETA INIA/3/DUKEM_12/2*RASCON_21/4/... & $\begin{array}{c}\text { CDSS04Y00362S- } \\
\text { 27Y-0M-06Y-4M- } \\
\text { 1Y-0B } \\
\end{array}$ & Rép1-13 \\
\hline 10 & Sigus & Témoin & Témoin \\
\hline 11 & LDN7D(7A)/3*ASCONCHI/3/SORA/2*PLATA_2*PLATA_12//... & $\begin{array}{c}\text { CDSS04Y01137T- } \\
\text { 0T0PB-24Y-0M- } \\
\text { 06Y-1M-1Y-0B }\end{array}$ & Rép1-24 \\
\hline 12 & ALTAR84/STINT//SILVER_45/3GUANAY/4GREEN_14//YAV_10/... & $\begin{array}{c}\text { CDSS04Y00341S- } \\
\text { 11Y-0M-06Y-3M- } \\
\text { 1Y-0B }\end{array}$ & Rép1-01 \\
\hline 13 & TARRO_1/2*YUAN_1//AJAIA_13/YAZI/3/SOMAT_3/PHAX_1//... & $\begin{array}{c}\text { CDSS02B01143T- } \\
\text { 0T0PB-0Y-0M-7Y- } \\
\text { 4M-04Y-0B }\end{array}$ & Rép1-18 \\
\hline 14 & $\begin{array}{l}\text { LLARETA INIA/4/SKEST//HUI/TUB/3/SILVER/5/LHNKE/ } \\
\text { RASCON//... }\end{array}$ & $\begin{array}{l}\text { CDSS02B00574S- } \\
0 \mathrm{M}-12 \mathrm{Y}-06 \mathrm{Y}-2 \mathrm{M}- \\
\text { 1Y-0B }\end{array}$ & Rép1-14 \\
\hline 15 & Waha & Témoin & Témoin \\
\hline 16 & Vitron & Témoin & Témoin \\
\hline 17 & Echams & Témoin & Témoin \\
\hline
\end{tabular}




\section{MATERIALS AND METHODS}

Field experiment

The experiment was carried out during the growing season of 2013-2014 at National Institute of Agronomic Research of Algeria (Long: $3^{\circ} 6^{\prime} \mathrm{E}$, lat: $36^{\circ} 41^{\prime} \mathrm{N}$, alt: $18 \mathrm{~m}$ above sea level). Twelve lines selected from the international trials of CIMMYT (Mexico) and five varieties originated from Algeria were sown in pot culture (five seedling per pot) and in a greenhouse. Each pot contained $5 \mathrm{Kg}$ of mixture of organic matter, clay silt soil and sand (1:1:1). The characteristics of the varieties studied are presented in table 1.

The experimental design adopted, in this experiment, is that of a split plot design with two water regimes as main plot and 17 varieties as sub plots and three replications. The water stress treatment was imposed when the $6^{\text {th }}$ leaf started to appear by stopping the irrigation, followed by a hydration period. The control plants were irrigated every two days.

Proline determination. Proline colorimetric determination proceeded according to Troll and Lindsley (1955) method modified by Magne and Laher (1992). Leaves were collected and etuved at $65^{\circ} \mathrm{C}$ for 48 Hours. $50 \mathrm{mg}$ of Dry weight were homogenized with $1 \mathrm{ml}$ of distilled water and kept in water bath for $30 \mathrm{mn}$. Then centrifuged at $13000 \mathrm{xg}$ for $15 \mathrm{mn}$ and supernatant was separated. One millilitre of the extract was taken and $2 \mathrm{ml}$ of acid ninhydrine reagent were added and placed in a water bath at $100^{\circ} \mathrm{C}$ for $30 \mathrm{mn}$. The cromophore was extracted with $3 \mathrm{ml}$ of toluene and its absorbance at $520 \mathrm{~nm}$ was determined in a spectrophotometer (SHIMADZU). The proline content is expressed in $\mu \mathrm{g} / \mathrm{mg}$ of dry weight basis. The method was calibrated for each determination with standard proline solutions.

Statistical analysis: The results were analyzed by using GenStat Discovery, version4, ANOVA twoway (in randomized blocks).

\section{RESULTS AND DISCUSSION}

The results show an increase of proline accumulation under stress conditions,

While under well watered conditions (control), proline content in different genotypes remains low (Fig. 1).

The behavior of different genotypes under water stress showed variability in the accumulation of this amino acid „proline“. We have classified the cultivars according to their aptitude to accumulate proline; 04 groups were identified (Fig. 2).

1) The variety $\mathrm{N} 5=$ Beni Mestina was characterized by high accumulation of proline $133.7 \mu \mathrm{g} / \mathrm{mg}$ of dry matter and with a percentage increase of $288 \%$ under water stress conditions.

2) Genotypes characterized by an average accumulation of proline which were between

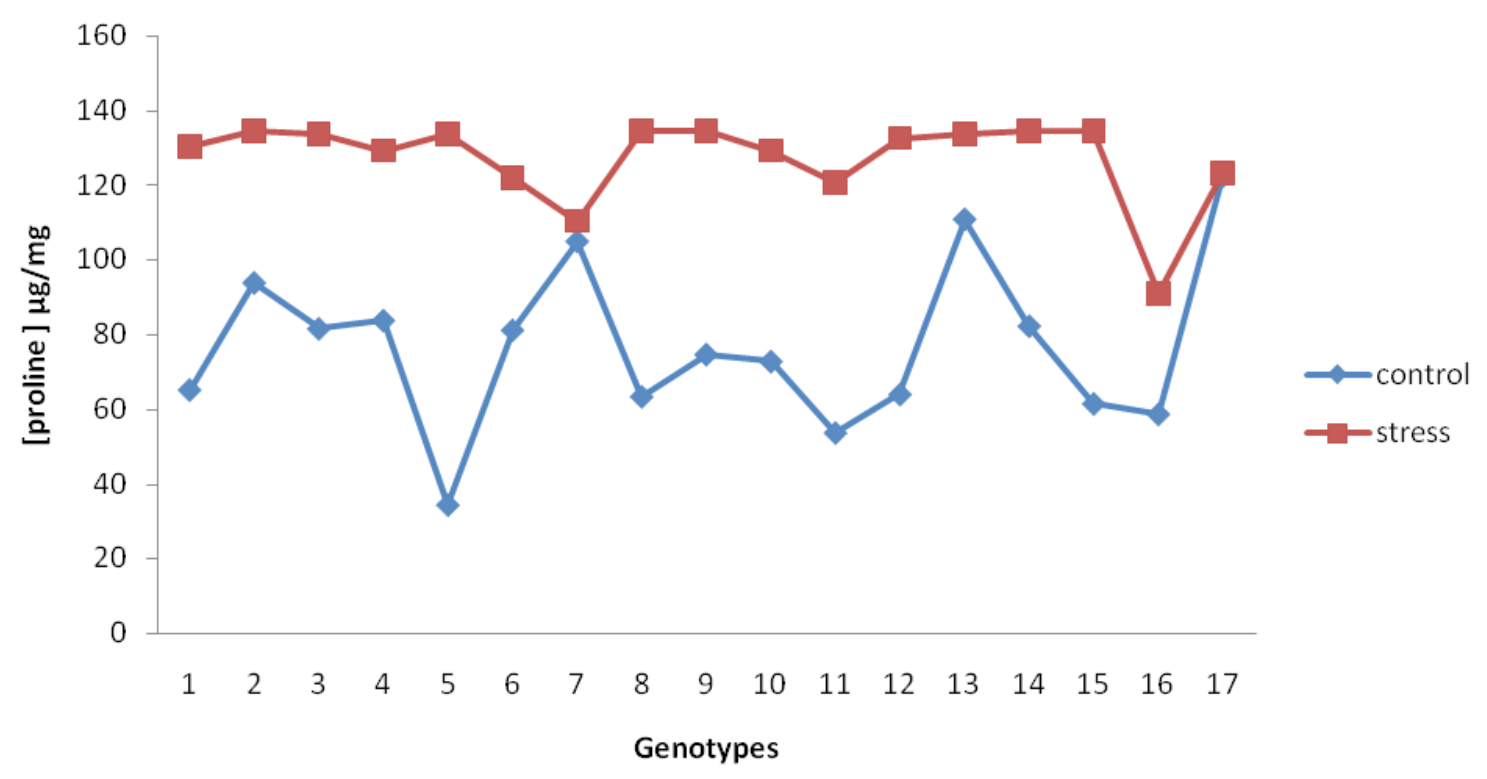

Fig. 1. The proline content of last leave under watred and stress conditions on some genotypes of Durum Wheat (Triticum durum Desf.). 


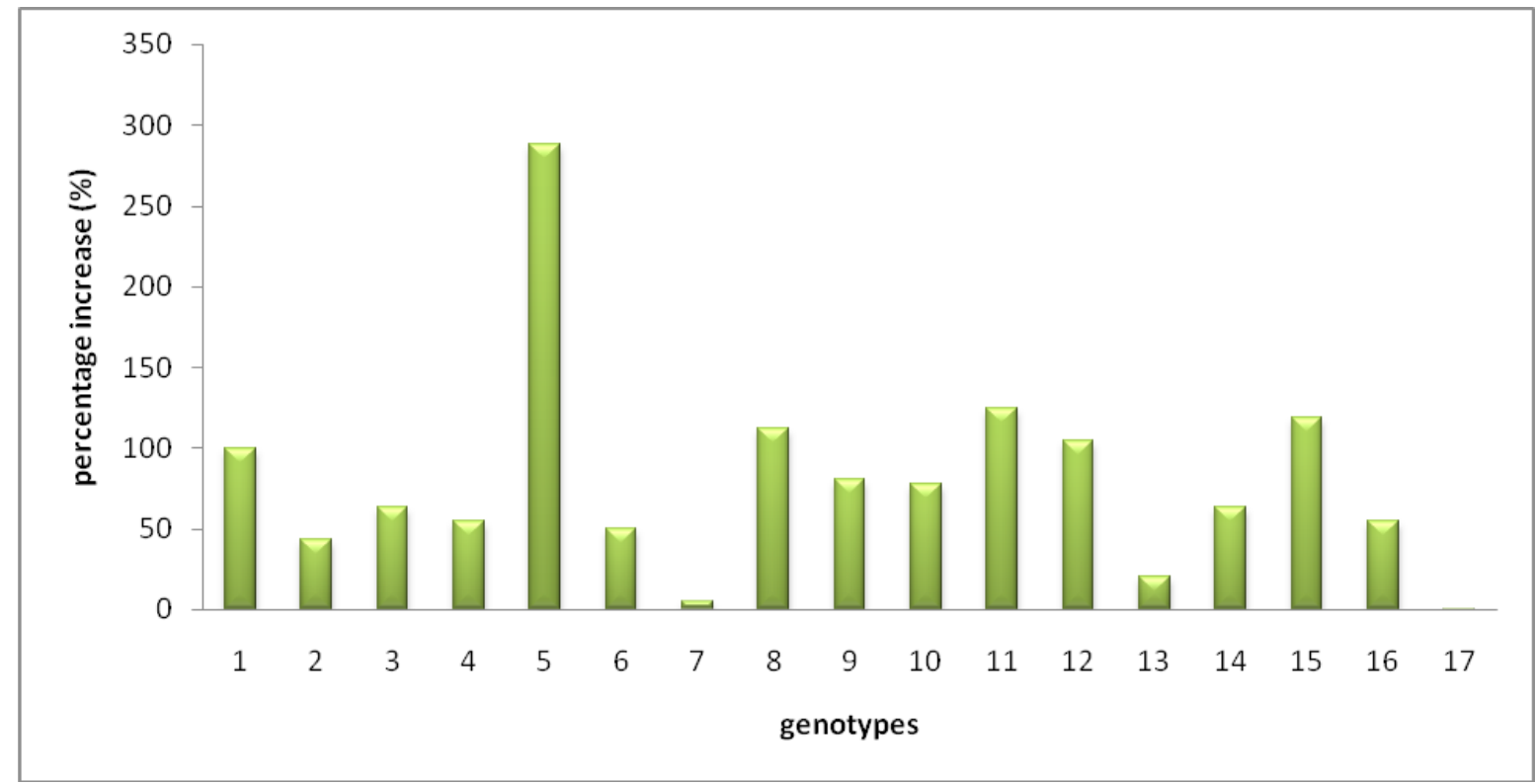

Fig. 2. The percentage increase of proline content under water stress conditions, on some genotypes of Durum Wheat (Triticum durum Desf.).

$100 \mu \mathrm{g} / \mathrm{mg}$ and $200 \mu \mathrm{g} / \mathrm{mg}$ are: $1,8,11,12$ and 15.

3) An intermediate group was identified according to theirs haptitude to accumulated proline and which were between $6 \mu \mathrm{g} / \mathrm{mg}$ and $100 \mu \mathrm{g} / \mathrm{mg}$ are: $3,4,6,9,10,14,16,2$ and 13 .

4) Genotypes characterized by very reduced accumulation of proline $(<6 \mu \mathrm{g} /$ mg) under water stress conditions, was about $110.4 \mu \mathrm{g} / \mathrm{mg}(5.14 \%)$ and $123.2 \mu \mathrm{g} /$ mg $(0.57 \%)$ respectively for PLATA_1// SOMAT_3/3CABECA_2/PATKA_4//ZHONG ZUO/. Line and Echams variety.

The results showed that variability within cultivars $(p<0.003)$ and differences between treatments $(p<0.001)$ were significant. Under stress conditions, proline accumulation was highest. Proline accumulation which is often considered as an excellent marker of resistance to stress hydrique, increased significantly $(\mathrm{p}<0.01)$ under water stress conditions (Tab. 2). The results showed that Beni Mestina variety is highly resistant with a production rate of $133.7 \mu \mathrm{g} / \mathrm{mg}$ (288\%) while PLATA_1 // SOMAT_3 / 3CABECA_2 / PATKA_4 // ZHONG ZUO / . line and the Echams variety are sensitive with rate of accumulation proline respectively $110.4 \mathrm{\mu g} / \mathrm{mg}$ (5.14\%) and $123.2 \mu \mathrm{g} / \mathrm{mg}(0.57 \%)$ under water stress conditions. The others cultivars of germoplasm studied are resistant.

Proline accumulation has been demonstrated in many species and in different situations of stress (osmotic,water and heat) as osmolyte involved in protective mechanisms during abiotic stress (AlRumaih and Al-Rumaih, 2008).

Increasing the amount of proline is positively related to the fall of the water level in the plants. This result is confirmed by several scientific research, montionning those of Monneveux et Nemmar (1986), Bellinger et al. (1991) et Gorham (1993).

Many studies report that proline accumulated in plants under unfavorable conditions (Sivaramakrishnan et al., 1988) which reflects the character of resistance to water stress (Greenway

Tab. 2. Analysis of variance for proline determination.

\begin{tabular}{cccccccc}
\hline & \multicolumn{2}{c}{ Effect of genotypes } & \multicolumn{2}{c}{ Effect of water } & \multicolumn{3}{c}{ Interaction Gen*Water } \\
\hline & $\mathrm{F}$ & $\mathrm{Pr}$ & $\mathrm{F}$ & $\mathrm{Pr}$ & $\mathrm{F}$ & $\mathrm{Pr}$ \\
\hline Proline content & 324.45 & 0.003 & 3.41 & $<.001$ & 3.49 & $<.001$ \\
\hline
\end{tabular}


and Munns, 1988). According Quien et al. (2001), accumulation proline under water stress contributes to the development of resistance by maintaining cell turgor, created by osmotic adjustment.

\section{CONCLUSION}

At conclusion, the study showed that our germoplasm of durum wheat is resistant with the exeption of two genotypes PLATA_1 SOMAT_3/3CABECA_4//ZHONG ZUO/. Line and Echams variety are sensitive. All genotypes have developed the same strategy which is the proline accumulation under water stress, except that they different by the production rate of this amino acid. Proline accumulation can be a real biochemical mechanism of resistance to water deficit in durum wheat.

\section{REFERENCES}

1. Al-Rumaih MM, Al-Rumaih MM (2008). Infuluence of ionizing radiation on antioxidant onzymes in there species of Trigonelle. Am. J. Enviren. Sci., 4:151-156.

2. Berllinger Y, Bensaoud A, Larher F (1991). Physiological significance of proline accumulation, a trait of use to breeding for stress tolerance. In: Acevedo, E., Conesa, A.P., Monneveux, P. and Srivastava, J.P. (Eds). PhysiologyBreeding of winter cereals for stressed Mediterranean environments. Montpellier, France, 55:449-458.

3. Casals ML (1996). Introduction des mécanismes de résistance à la sécheresse dans un modèle dynamique de croissance et de développement du blé dur. Thèse de Doctorat de l'INRA Paris Grignon.

4. El Mourid M (1988). Performance of wheat and barley cultivars under different soil moisture regimes in semi arid region. Ph.D. dissertation, Iowa State University Ames USA.

5. El Mourid M, Karrou M, El Gharous M (1996). La recherche en aridoculture respectueuse de l'environnement. $\mathrm{Al}$ Awamia. 92:69-81.
6. Gorham J (1993). Stress tolerance and mechanisms behind tolerance in barley. In: Agronomical and physiological characterization of different barley genotypes to salt stress. Settat 1993, meeting.

7. Greenway H. \& R. Munns. (1988). Mechanims of salt tolerance in non halophytes. Annual Review of Plant Phyiology,25:149190.

8. Hare PD, Cress WA (1997). Metabolic implications of stress induced proline accumulation in plants. Plant Growth Regulation, 21:79102.

9. Magne C, Laher F (1992). Hight sugar content of extracts inerferes with colorimetric determination of amino acids and free proline. Anal. Biochem., 200:115-118.

10. Monneveux P, Nemmar $\mathrm{M}$ (1986). Contribution à l'étude de la résistance à la sécheresse chez le blé tendre $(T$. aestivum L) et chez le blé dur (T.durum Desf.). Etude de l'accumulation de la proline au cours du cycle de développement. Agronomie, 6(6):583-590.

11. Qian YL, Wilhelm SJ, Marcum KB (2001). Comparative Responses of Two Kentucky Bluegrass Cultivars to Salinity Stress. Crop Science, 41 :1895-1900.

12. Savitsyay NN (1967). Problem of accumulation of free proline in barley plant under conditions of soil water deficiency. Fiziol. Rast., 14 :737-739.

13. Singh TN, Plag LG, Aspinall D (1973a). Stress metabolism I : Nitrogen metabolism and growth in barley plant during water stress. Aust. J. Biol. Sci., $26: 45-56$.

14. Sivaramakrishnan S, Pattel V, Flower G, Paleg LG (1988). Proline accumulation and nitrate reductase activity in contrasting sorghum lines during mid season drought stress. Plant Physiol.,74 :418-426.

15. Tyankova LA (1967). Effects of I.A.A. and 2,4-D on free and bound amino acids in wheat plants recovering after breif drought treatements. Field Crop Abstr., 1531(20):3.

16. Vlasyuk PA, Shmatkoi G, Rubanyuk EA (1968). Role of the trace elements zinc and boron in amino acid metabolism and drought resistance of winter wheat. Fiziol. Rast., 15:281-287.

17. Wang WX, Brak T, Vinocur B, Shoseyov O, Altman A (2003). Abiotic resistance and chaprones: possible physiological role of SP1, a stable and stabilising protein from Populus. In: Vasil IK (ed), Plant biotechnology 2000 and beyond. Kluwer, Dordrecht. 